\title{
Evidence for two types of nicotinic receptors in the cat carotid body chemoreceptor cells
}

\author{
Ana Obeso ${ }^{\text {a }}$, María Angeles Gómez-Niño a , Laura Almaraz a , Bruce Dinger ${ }^{\mathrm{b}}$, Salvatore Fidone ${ }^{\mathrm{b}}$, \\ Constancio González ${ }^{\text {a, * }}$ \\ a Departamento de Bioquímica y Biología Molecular y Fisiología, Facultad de Medicina, Universidad de Valladolid, 47005 Valladolid, Spain \\ ${ }^{\mathrm{b}}$ Department of Physiology, University of Utah School of Medicine, Salt Lake City, UT, USA
}

Accepted 4 February 1997

\begin{abstract}
Current concepts on the location and functional significance of nicotinic receptors in the carotid body rest on $\alpha$-bungarotoxin binding and autoradiographic studies. Using an in vitro preparation of the cat carotid body whose catecholamine deposits have been labeled by prior incubation with the tritiated natural precursor $\left[{ }^{3} \mathrm{H}\right]$ tyrosine, we have found that nicotine induces release of $\left[{ }^{3} \mathrm{H}\right]$ catecholamines in a dose-dependent manner $\left(\mathrm{IC}_{50}=9.81 \mu \mathrm{M}\right)$. We also found that mecamylamine $(50 \mu \mathrm{M})$ completely abolished the nicotine-induced release, while $\alpha$-bungarotoxin $\left(100 \mathrm{nM} ; \approx 20\right.$ times its binding $K_{\mathrm{d}}$ ) only reduced the release by $56 \%$. These findings indicate that chemoreceptor cells, and perhaps other carotid body structures, contain nicotinic receptors that are not sensitive to $\alpha$-bungarotoxin and force a revision of the current concepts on cholinergic mechanisms in the carotid body chemoreception.
\end{abstract}

Keywords: Carotid body; Nicotinic receptor; Nicotine; $\alpha$-Bungarotoxin; Catecholamine

The significance of acetylcholine (ACh) in the carotid body (CB) arterial chemoreceptors has been debated throughout the history of arterial chemoreceptors. Heymans et al. $[17,18]$ discovered that nicotine and exogenous $\mathrm{ACh}$, acting at the level of the $\mathrm{CB}$, can evoke respiratory reflexes comparable to those produced by hypoxia and acidosis, and Schweitzer and Wright [24] observed that prostigmine (an inhibitor of ACh-esterase) mimicked the action of ACh. These findings lead to the proposal that $\mathrm{ACh}$ would be the neurotransmitter mediating the activation of the sensory nerve endings of the carotid sinus nerve (CSN). This proposal, known as the cholinergic hypothesis of CB chemoreception, was highly debated, and in the sixties Eyzaguirre's laboratory accumulated sound experimental evidence to support a nicotinic receptor-mediated role for ACh in the genesis of the activity in the CSN, in response to a variety of stimuli [9]. However, the controversy continued because classical nicotinic blockers suppressed the excitatory actions of nicotinic agonists, but only reduced in a variable percentage the activation produced by natural stimuli $[20,21]$.
Biochemically, it was shown that the $\mathrm{CB}$ contains ACh $[12,16]$, expresses an adequate activity of choline acetyl transferase [16], accumulates choline by a high affinity system, and exhibits a high turnover rate for ACh [10]. In spite of all these data, the role of ACh in the chemoreception process remained elusive. Radioligand binding and autoradiographic studies, using $\left[{ }^{125} \mathrm{I}\right] \alpha$-bungarotoxin $(\alpha$ $\mathrm{BT})$ as ligand in normal, CSN-denervated and sympathectomized CBs, showed that the high affinity specific binding was located in chemoreceptor cells and sympathetic endings, but not in sensory nerve endings $[4,5]$. Electrophysiological studies have also shown the presence of nicotinic receptors in chemoreceptor cells [15,25], and neurochemically it has been shown that chemoreceptor cells release catecholamines (CA) in response to nicotinic agonists $[5,14]$. These findings have been considered to indicate that $\mathrm{ACh}$ acts as a secondary neurotransmitter exclusively on the presynaptic side of the chemoreceptor cell-sensory nerve ending synapse $[11,13]$.

There is, however, a finding that was not satisfactorily explained: while classical nicotinic blockers fully eliminated the nicotine-mediated excitation of the CSN $[9,20]$, $\alpha$-BT at a concentration near 10 times the $K_{\mathrm{d}}$, inhibited by only $\approx 50 \%$ the release of CA and CSN discharges elicited

\footnotetext{
* Corresponding author. Fax: +34 (83) 423588.
} 
by nicotine [5]. In the light of recent advances in the biology of the nicotinic receptor [3,19,23] we have tested the possibility that chemoreceptor cells express two functional subtypes of nicotinic receptors, one sensitive and another insensitive to $\alpha$-BT. Using an in vitro preparation of cat $\mathrm{CB}$ whose catecholamine (CA) deposits have been labeled by incubation with the natural precursor $\left[{ }^{3} \mathrm{H}\right]$ tyrosine, we have found that $\alpha$-BT, at concentrations 20 times above its binding $K_{\mathrm{d}}$, inhibits the nicotine evoked release of $\left[{ }^{3} \mathrm{H}\right] \mathrm{CA}$ by only $56 \%$, while the classical nicotine blocker mecamylamine at $50 \mu \mathrm{M}$ inhibited the nicotineevoked release by $100 \%$. These findings imply that chemoreceptor cells express nicotinic receptors containing $\alpha_{7}-\alpha_{8}$ subunits and thereby sensitive to $\alpha$-BT [19,23], and other subtypes of nicotinic receptors with different $\alpha$ subunits insensitive to the toxin.

Experiments were performed with $\mathrm{CBs}$ of adult cats $(2.5-3.5 \mathrm{~kg})$. The animals were anesthetized with sodium pentobarbital (40 mg/kg; i.p.), and after tracheotomy, the carotid bifurcations were identified, removed and placed in a lucite chamber containing ice-cold modified Tyrode (in $\mathrm{mM}$ ): $\mathrm{NaCl}, 112 ; \mathrm{KCl}, 4.7 ; \mathrm{CaCl}_{2}, 2.2 ; \mathrm{MgCl}_{2}, 1.1$; sodium glutamate, 42; HEPES, 5; glucose, 5.5) [2] at $\mathrm{pH}$ 7.40 and equilibrated with $100 \% \mathrm{O}_{2}$.

Under a dissecting microscope the CBs were cleaned of surrounding tissue and thereafter incubated in glass vials containing $2 \mathrm{ml}$ of Tyrode placed in a metabolic shaker at a constant temperature of $37^{\circ} \mathrm{C}$. The incubating solution contained $100 \mu \mathrm{M}$ 6-methyl-tetrahydropterine (a tyrosine hydroxylase cofactor), $1 \mathrm{mM}$ ascorbic acid (as a cofactor of dopamine- $\beta$-hydroxylase) and $40 \mu \mathrm{M}\left[{ }^{3} \mathrm{H}\right]$ tyrosine (20 $\mathrm{Ci} / \mathrm{mM}$; Amersham), the natural precursor of catecholamines (CA). After $2 \mathrm{~h}$ of incubation CA deposits were labeled so that each $\mathrm{CB}$ has synthesized $\approx 12 \mathrm{pmol}$ of $\left[{ }^{3} \mathrm{H}\right]$ dopamine (DA), equivalent to $\approx 3 \times 10^{5}$ d.p.m., and $\approx 1$ pmol of $\left[{ }^{3} \mathrm{H}\right]$ norepinephrine $(\mathrm{NE})$, equivalent to $\approx 3$ $\times 10^{4}$ d.p.m. After the labeling period the organs were transferred to new vials containing $4 \mathrm{ml}$ of precursor-free Tyrode continuously bubbled with $100 \% \mathrm{O}_{2}$ saturated with water vapor. The solution was renewed every $30 \mathrm{~min}$ during $2 \mathrm{~h}$ and discarded; in this washing period most of the precursor as well as the labile pool of labeled CA were lost, and afterwards the basal release of $\left[{ }^{3} \mathrm{H}\right] \mathrm{CA}$ was stable for several hours [1]. Thereafter the incubating solutions were renewed every $10 \mathrm{~min}$ and collected for the ulterior analysis in their $\left[{ }^{3} \mathrm{H}\right] \mathrm{CA}$ content.

The collection of incubating solutions was grouped in stimulation cycles, each cycle consisting in a control sample to determine the basal release, a stimulus sample corresponding to the incubating period in the presence of the agent(s) tested, and several post-stimulus samples corresponding to periods of incubation with control solutions until the release of $\left[{ }^{3} \mathrm{H}\right] \mathrm{CA}$ returned to the basal level (see Fig. 1A). Nicotinic blockers (i.e., mecamylamine and $\alpha$ BT) were included in the control period(s) prior to nicotine application to assure an adequate diffusion of the drug and block of nicotinic receptors. A given preparation could be subjected to one or more stimulation cycles depending on the reversibility of the effect of the agent under study. The analysis of the released $\left[{ }^{3} \mathrm{H}\right] \mathrm{CA}$ included: acidification of the collected incubating solutions to $\mathrm{pH} 3.2$ with a mixture of glacial acetic and ascorbic acid to avoid degradation of CA, bulk adsorption of all catechols released into alumina at a $\mathrm{pH}$ of 8.6, intense washing of alumina columns with distilled water and bulk elution of all catechols with $1 \mathrm{~N}$ $\mathrm{HCl}$. Part of the eluate was used to determine the total amount of $\left[{ }^{3} \mathrm{H}\right] \mathrm{CA}$ released in each period by liquid scintillation spectrometry, and the rest was pooled with correspondent samples of a total of four experiments, dried under vacuum, resuspended in the mobile phase containing unlabeled catechols as carriers of the labeled substances, and high performance liquid chromatographied to identify
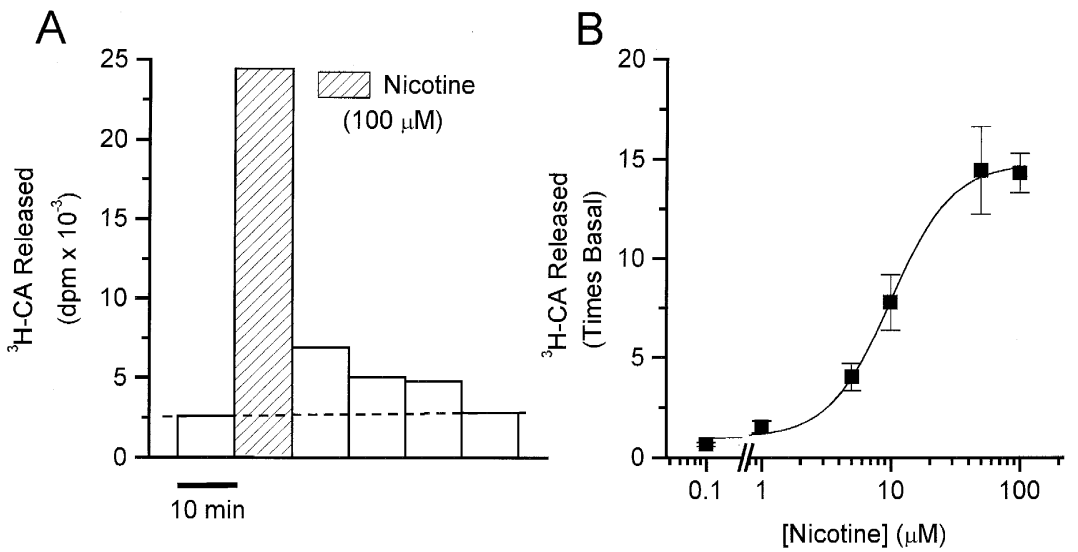

Fig. 1. A: a stimulation cycle to show the time course of the release of $\left[{ }^{3} \mathrm{H}\right]$ catecholamines induced by $100 \mu \mathrm{M}$ nicotine in the cat carotid body. The line crossing the histogram separates graphically the basal release (below) from the evoked release (above). B: log dose-response curve for nicotine on the release of $\left[{ }^{3} \mathrm{H}\right]$ catecholamine by the cat carotid body. The release response is expressed as times basal release. Data were fitted to the following function: $\mathrm{y}=\mathrm{A}_{2}-\mathrm{A}_{2} /\left[1+\left(\mathrm{x} / \mathrm{x}_{0}\right)^{p}\right]$, where $\mathrm{A}_{2}$ is the maximum effect, $\mathrm{x}$ is the concentration of nicotine, $\mathrm{x}_{0}$ is the $\mathrm{IC}_{50}$ and $p$ is the Hill coefficient. The $\mathrm{IC}_{50}$ was $9.81 \mu$ M. Data are means \pm S.E.M.; $n=6$. 
the actual $\left[{ }^{3} \mathrm{H}\right]$ catechol released (for chromatographic details see ref. [14]). The effect of a given agent on the release of $\left[{ }^{3} \mathrm{H}\right] \mathrm{CA}$ was calculated in two different ways: first, the evoked release (above the dashed line in Fig. 1A) was referred to the basal release prior the application of the stimulus and expressed as times basal release, and second, the evoked release by a given stimulus was referred to the tissue content and expressed as percent of the tissue content.

The significance of the effects observed was assessed with a two-tailed Student $t$-test for paired or unpaired data according to experimental design.

Effects of nicotine on the release of $\left[{ }^{3} \mathrm{H}\right] \mathrm{CA}$. Fig. 1A shows a stimulation cycle with $100 \mu \mathrm{M}$ nicotine. Nicotine-induced release of $\left[{ }^{3} \mathrm{H}\right] \mathrm{CA}$ is represented by the d.p.m. above the dashed line crossing the histogram. Note that nearly $80 \%$ of the evoked release is collected during the 10 min period corresponding to the nicotine application, and that during the post-stimulus periods there is a slow decline of the release to reach basal pre-stimulation levels. This slow phase of the evoked release is represented by the washing-out of $\left[{ }^{3} \mathrm{H}\right] \mathrm{CA}$ catabolites; a part the $\left[{ }^{3} \mathrm{H}\right] \mathrm{CA}$ released during the stimulus period is taken out by the tissues and degraded, and the $\left[{ }^{3} \mathrm{H}\right]$ catabolites are slowly disposed by the cells. Fig. 1B shows a dose-effect curve for nicotine on the release of $\left[{ }^{3} \mathrm{H}\right] \mathrm{CA}$. The evoked release is expressed as times basal release. At the lowest concentration tested $(0.1 \mu \mathrm{M})$, nicotine increased the release of $\left[{ }^{3} \mathrm{H}\right] \mathrm{CA}$ by a factor of 0.65 above basal release; maximal response, corresponding to a release of 14.4 times above basal was obtained with $50 \mu \mathrm{M}$ nicotine, and the nicotine concentration producing half maximal effect $\left(\mathrm{IC}_{50}\right)$ was $9.81 \mu \mathrm{M}$. The same $\mathrm{IC}_{50}$ was obtained if the evoked release was expressed as percentage of tissue content, the

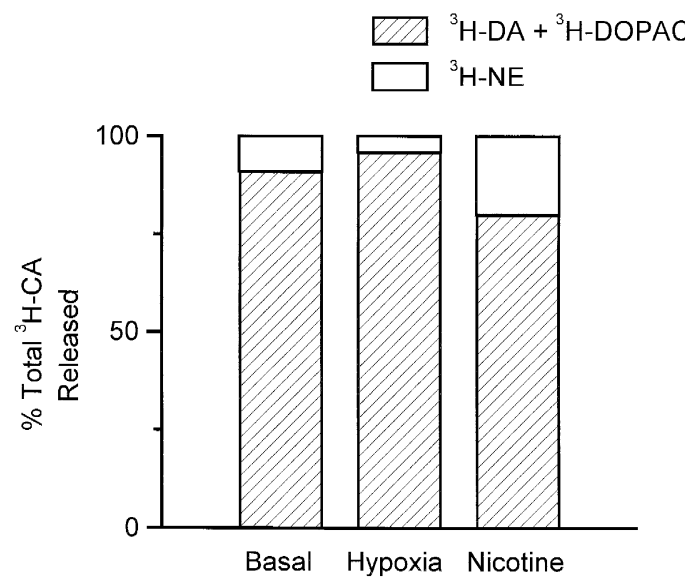

Fig. 2. Analytical profile of the $\left[{ }^{3} \mathrm{H}\right]$ catechol released. In basal conditions $\left[{ }^{3} \mathrm{H}\right]$ dihydroxyphenyl acetic acid (DOPAC), the main catabolite of $\left[{ }^{3} \mathrm{H}\right]$ dopamine, represented $60 \%$ of the total $\left[{ }^{3} \mathrm{H}\right]$ catechols released. During hypoxic stimulation $\left[{ }^{3} \mathrm{H}\right] \mathrm{DOPAC}$ amounted to $20 \%$ of the released material and during nicotinic stimulation it represented $17 \%$. The catabolites of $\left[{ }^{3} \mathrm{H}\right]$ norepinephrine were below detection.

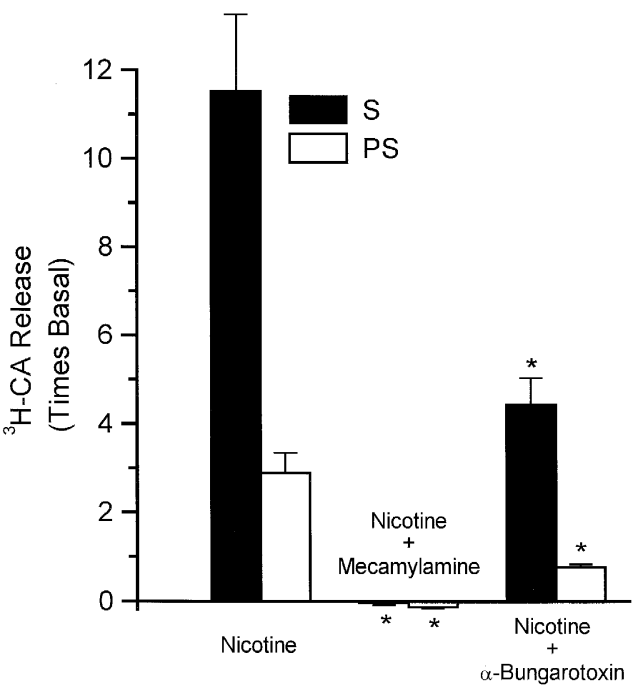

Fig. 3. Effects of mecamylamine and $\alpha$-bungarotoxin on the release of $\left[{ }^{3} \mathrm{H}\right]$ catecholamines elicited by nicotine. The left group of columns represents the release of $\left[{ }^{3} \mathrm{H}\right] \mathrm{CA}$ elicited by $50 \mu \mathrm{M}$ nicotine during the stimulus (S) and the post-stimulus (PS) periods. The middle group of columns shows the complete inhibition of the nicotine $(50 \mu \mathrm{M})$ release response produced by $50 \mu \mathrm{M}$ mecamylamine, and the right group of columns corresponds to the release of $\left[{ }^{3} \mathrm{H}\right] \mathrm{CA}$ produced by nicotine $(50$ $\mu \mathrm{M})$ in the presence of $100 \mathrm{nM} \alpha$-bungarotoxin. Data are means \pm S.E.M.; $n=6$ for nicotine and nicotine plus mecamylamine and $n=8$ for nicotine plus $\alpha$-bungarotoxin. ${ }^{*} P<0.001$ in all the cases.

basal release in a 10 min period representing $0.5 \%$ of the tissue content.

Fig. 2 shows the analytical profile of the $\left[{ }^{3} \mathrm{H}\right]$ catechols found in basal samples, in incubating samples corresponding to the stimulation with nicotine $(50 \mu \mathrm{M})$, and for comparative purposes in incubating samples corresponding to stimulation with hypoxia (incubation with $10 \% \mathrm{O}_{2}$-equilibrated solutions). The ratio for $\left[{ }^{3} \mathrm{H}\right] \mathrm{DA} /\left[{ }^{3} \mathrm{H}\right] \mathrm{NE}$ found in basal samples was 10.5 , indicating that $91 \%$ of the total $\left[{ }^{3} \mathrm{H}\right] \mathrm{CA}$ released was $\left[{ }^{3} \mathrm{H}\right] \mathrm{DA}$ and the remaining $9 \%$ was $\left[{ }^{3} \mathrm{H}\right] \mathrm{NE}$. These percentages are comparable to those found in the tissues [22], indicating that in basal conditions both $\left[{ }^{3} \mathrm{H}\right] \mathrm{CA}$ are released at a rate proportional to their tissue levels. During hypoxic stimulation the release of both $\left[{ }^{3} \mathrm{H}\right] \mathrm{CA}$ increased, and the $\left[{ }^{3} \mathrm{H}\right] \mathrm{DA} /\left[{ }^{3} \mathrm{H}\right] \mathrm{NE}$ ratio in the collected samples increased to 23 , indicating a preferential release of $\left[{ }^{3} \mathrm{H}\right] \mathrm{DA}$. On the contrary, during nicotinic stimulation the ratio of $\left[{ }^{3} \mathrm{H}\right] \mathrm{DA} /\left[{ }^{3} \mathrm{H}\right] \mathrm{NE}$ in the collected samples dropped to a value of 4 , indicating a preferential release of $\left[{ }^{3} \mathrm{H}\right] \mathrm{NE}$. Even a more marked preferential release of $\left[{ }^{3} \mathrm{H}\right] \mathrm{NE}$ during nicotinic stimulation has been previously reported in the rabbit CB [14].

Fig. 3 shows the effect of $\alpha$-BT and mecamylamine on the release of $\left[{ }^{3} \mathrm{H}\right] \mathrm{CA}$ elicited by nicotine. Since in previous experiments it was found that maximal $\alpha$-BT binding was attained in $30 \mathrm{~min}$ (see ref. [5]), the toxin was included in the incubating solution for the three $10 \mathrm{~min}$ control periods prior to and during nicotine application; 
mecamylamine was included in the incubating solution for a single $10 \mathrm{~min}$ control period prior to and during nicotine application. Note that mecamylamine $(50 \mu \mathrm{M})$ completely blocked the release induced by an identical concentration of nicotine. However, $\alpha$-BT at a concentration of $100 \mathrm{nM}$, which is nearly 20 times its $K_{\mathrm{d}}$ in binding experiments [5], only inhibited the nicotine-induced release by $56 \%$. This level of inhibition is identical to that obtained with $50 \mathrm{nM}$ $\alpha$-BT [5], and therefore it was not necessary to test higher concentrations. Neither nicotinic blocker affected the control unstimulated or basal release of $\left[{ }^{3} \mathrm{H}\right] \mathrm{CA}$.

The main finding of this work is that mecamylamine completely inhibits the release of $\left[{ }^{3} \mathrm{H}\right] \mathrm{CA}$ while $\alpha$-BT only inhibits $56 \%$, indicating that there is a set of nicotinic receptors in the $\mathrm{CB}$ that is insensitive to $\alpha$-BT. These results also imply that the current concepts concerning the identification and location of nicotinic receptors in the $\mathrm{CB}$, which are based on $\alpha$-BT binding and autoradiographic experiments, need to be revised.

The dose-response for nicotine on the release of $\left[{ }^{3} \mathrm{H}\right] \mathrm{CA}$ obtained in the present study is displaced to the right when compared to that obtained by Eyzaguirre and Zapata [7] for $\mathrm{ACh}$ on the cat CSN discharges. They reported a threshold for the response of $68 \mathrm{nM}\left(10^{-8} \mathrm{~g} / \mathrm{ml}\right)$, an $\mathrm{IC}_{50}$ of $\approx 0.68 \mu \mathrm{M}$ and a maximal response at $\approx 6.8 \mu \mathrm{M}$; these values indicate a displacement to the right by more than an order of magnitude of the dose-response curve reported here. A ready explanation for this difference could be that ACh increases CSN discharges acting on sensory nerve endings and not on chemoreceptor cells; alternatively, the CA released from chemoreceptor cells could represent the drivers of the CSN discharges, in such a way that small increases in the release above basal produce significant increases in the CSN discharges, and submaximal release produces maximal CSN action potential frequency (see below). It is impossible to compare our data with those obtained in other studies, because in most of them ACh or nicotine were administered intra-arterially as bolus injections or in the inflowing tubing to the recording chamber. The preferential release of $\left[{ }^{3} \mathrm{H}\right] \mathrm{NE}$ observed during nicotinic stimulation correlates with the observation that nearly $40 \%$ of the $\alpha$-BT binding sites disappear after chronic CB sympathectomy [5] and indicate that a significant part of the $\left[{ }^{3} \mathrm{H}\right] \mathrm{NE}$ released comes from intraglomic sympathetic endings. In fact, and contrary to the situation in the rabbit [14], the preferential release of $\left[{ }^{3} \mathrm{H}\right] \mathrm{NE}$ observed under nicotinic stimulation in the cat $\mathrm{CB}$ disappears after sympathectomy (Gómez-Niño, unpublished).

Our findings with mecamylamine vs. $\alpha$-BT clearly demonstrate that part of the nicotinic receptors in the cat $\mathrm{CB}$ are not sensitive to the snake toxin. Although the present pharmacological study does not allow to identify the subtypes of nicotinic receptors, it is clear that chemoreceptor cells should express nicotinic receptors with $\alpha_{7}$ or $\alpha_{8}$ subunits, because only these subunits bind $\alpha$-BT; it is also clear that they must express nicotinic receptors with other $\alpha$ subunits, probably of the subtypes $\alpha_{3}$ or $\alpha_{5}$ which are the most commonly found in sympathetic neurons, and PC12 cells [19] which are embryologically related to the $\mathrm{CB}$. Our findings in turn indicate that previous identification of nicotinic receptors on the basis of $\alpha$-BT binding and autoradiographic studies have let out part of the nicotinic receptors in the $\mathrm{CB}$, and the possibility exists that a part of these missed receptors are located in the sensory nerve endings. The unambiguous answer to this possibility would require the demonstration of the receptors in the sensory nerve endings and/or the demonstration of the message for them in the chemoreceptor neurons of the petrosal ganglion by immunohistochemical and/or in situ hybridization techniques. However, the fact that nicotinic effects on CSN discharges are greatly diminished or abolished in $\mathrm{Ca}^{2+}$-free or $\mathrm{Mg}^{2+}$-rich solutions $[8,9]$ suggests that nicotinic receptors are predominantly or exclusively located in chemoreceptor cells, and thereby that nicotinic effects on CSN discharges are mediated via the $\mathrm{Ca}^{2+}$-dependent release of other neurotransmitters. In conclusion, the present data demonstrating that a part of the nicotinic receptors are not sensitive to $\alpha$-BT obligates a revision of the concepts of the cholinergic mechanisms in the CB chemoreceptors [6].

\section{Acknowledgements}

Supported by Spanish DGICYT Grant PB92 0267 and by NIH Grants NS07938 and NS12636.

\section{References}

[1] Almaraz, L., González, C. and Obeso, A., Effects of high potassium on the release of $\left[{ }^{3} \mathrm{H}\right]$ dopamine from the cat carotid body in vitro, $J$. Physiol. (Lond.), 379 (1986) 293-307.

[2] Baron, M. and Eyzaguirre, C., Effects of temperature on some membrane characteristics of carotid body cells, Am. J. Physiol., 233 (1977) C35-C46.

[3] Clarke, P.B.S., The fall and rise of neuronal alpha-bungarotoxin binding proteins, Trends Pharmacol. Sci., 13 (1992) 407-413.

[4] Dinger, B., González, C., Yoshizaki, K. and Fidone, S., Alphabungarotoxin binding in cat carotid body, Brain Res., 205 (1981) 187-193.

[5] Dinger, B., González, C., Yoshizaki, K. and Fidone, S., Localization and function of cat carotid body nicotinic receptors, Brain Res., 339 (1985) 295-304.

[6] Eyzaguirre, C., Fidone, S. and Nishi, K., Recent studies on the generation of chemoreceptor impulses. In: M.J. Purves (Ed.), The Peripheral Arterial Chemoreceptors, Cambridge University Press, London, 1975, pp. 175-194.

[7] Eyzaguirre, C. and Zapata, P., The release of acetylcholine from carotid body tissues. Further study on the effects of acetylcholine and cholinergic blocking agents on the chemosensory discharge, $J$. Physiol. (Lond.), 195 (1968) 589-607.

[8] Eyzaguirre, C. and Zapata, P., Pharmacology of $\mathrm{pH}$ effects on carotid body chemoreceptors in vitro, J. Physiol. (Lond.), 195 (1968) 557-588.

[9] Eyzaguirre, C. and Zapata, P., A discussion of possible transmitter 
or generator substances in carotid body chemoreceptors. In: R.W. Torrance (Ed.), Arterial Chemoreceptors, Blackwell Scientific Publications, Oxford, 1968, pp. 213-251.

[10] Fidone, S., Weintraub, S., Stavinoha, W., Stirling, C. and Jones, L., Endogenous acetylcholine levels in cat carotid body and the autoradiographic localization of a high affinity component of choline uptake. In: H. Acker, S. Fidone, D. Pallot, C. Eyzaguirre, D.W. Lübbers and R.W. Torrance (Eds.), Chemoreception in the Carotid Body, Springer-Verlag, Berlin, 1977, pp. 106-113.

[11] Fidone, S.J. and González, C., Initiation and control of chemoreceptor activity in the carotid body. In: A.P. Fishman (Ed.), Handbook of Physiology. The Respiratory System, Am. Physiol. Soc., Bethesda, MD, 1986, pp. 247-312.

[12] Fidone, S.J., Weintraub, S.T. and Stavinoha, W.B., Acetylcholine content of normal and denervated cat carotid bodies measured by pyrolysis gas chromatography/mass fragmentometry, J. Neurochem., 26 (1976) 1047-1049.

[13] González, C., Almaraz, L., Obeso, A. and Rigual, R., Carotid body chemoreceptors: from natural stimuli to sensory discharges, Physiol. Rev., 74 (1994).

[14] Gómez-Niño, A., Dinger, B., Gánzalez, C. and Fidone, S.J., Differential stimulus coupling to dopamine and norepinephrine stores in rabbit carotid body type I cells, Brain Res., 525 (1990) 160-164.

[15] Hayashida, Y. and Eyzaguirre, C., Voltage noise of carotid body type I cells, Brain Res., 167 (1979) 189-194.

[16] Hellstrom, S., Putative neurotransmitters in the carotid body. Mass fragmentographic studies, Adv. Biochem. Psychopharmacol., 16 (1977) 257-263.

[17] Heymans, C., Bouckaert, J.J. and Dautrebande, L., Sinus carotidien et réflexes respiratoires; sensibilité des sinus carotidiens aux sub- stances chimiques. Action stimulante respiratoire réflexe du sulfure de sodium, du cyanure de potassium, de la nicotine et de la lobéline, Arch. Int. Pharmacodyn. Ther., 40 (1931) 54-91.

[18] Heymans, C., Bouckaert, J.J., Farber, S. and Hsu, F.J., Influence réflexogène de l'acétylcholine sur les terminaisons nerveuses chimio-sensitives du sinus carotidien, Arch. Int. Pharmacodyn. Ther., 54 (1936) 129-135.

[19] McGehee, D.S. and Role, L.W., Physiological diversity of nicotinic acetylcholine receptors expressed by vertebrate neurons, Annu. Rev. Physiol., 57 (1995) 521-546.

[20] McQueen, D.S., A quantitative study of the effects of cholinergic drugs on carotid chemoreceptors in the cat, J. Physiol. (Lond.), 273 (1977) 515-532.

[21] McQueen, D.S., Pharmacological aspects of putative transmitters in the carotid body. In: H. Acker and R.G. O'Regan (Eds.), Physiology of the Peripheral Arterial Chemoreceptors, Elsevier Science, Amsterdam, 1983, pp. 149-195.

[22] Rigual, R., González, E., González, C., Jones, L. and Fidone, S., A comparative study of the metabolism of catecholamines in the rabbit and cat carotid body. In: J.A. Ribeiro and D.J. Pallot (Eds.), Chemoreceptors in Respiratory Control, Croom Helm, London, 1987, pp. 124-134.

[23] Sargent, P.B., The diversity of neuronal nicotinic acetylcholine receptors, Annu. Rev. Neurosci., 16 (1993) 403-443.

[24] Schweitzer, A. and Wright, S., Action of prostigmine and acetylcholine on respiration, Quart. J. Exp. Physiol., 28 (1938) 33-47.

[25] Wyatt, C.N. and Peers, C., Nicotinic acetylcholine receptors in isolated type I cells of the neonatal rat carotid body, Neuroscience, 54 (1993) 275-281. 